\title{
FAMILIENGESCHICHTE UND RUSSLANDINTERESSE
}

Am 3. Mai kamen die Russen in unser Dorf. ${ }^{1}$ Den als besonders indoktriniert geltenden Einheiten der 2. Belorussischen Front ging unter der Zivilbevölkerung ein schlechter Rufvoraus. Die überwiegende Mehrheit der 53000 starken Truppe, fast die Hälfte von ihnen Parteimitglieder und Komsomolzen, stammte vermutlich aus Weißrussland (Vgl. SchulzNaumann 1989, 156), das den Terror und die Verbrechen der deutschen Besatzung erlebt hatte. Im Schulhaus, das wir als Lehrerfamilie bewohnten, herrschte schockstarre Erwartungsangst. Die meisten Wohnräume und alle Klassenzimmer waren mit Menschen voll gestopft. Der Krieg im Osten trieb sie massenweise vor sich her nach Westen. Abends kamen Familien aus dem Ort zum Übernachten, weil sie sich hier unter vielen Leuten sicherer fühlten, als allein in ihren Häusern. Im Garten des gegenüberliegenden Bauerngehöfts fand man die Leichen des Besitzerpaares und ihrer beiden Söhne. Einige Dorfbewohner hatten Schreie gehört. Der Bauer hatte sich bei den auf seinem Hof arbeitenden Kriegsgefangenen verhasst gemacht. Aber es konnte auch Selbstmord gewesen sein, aufgeklärt wurde der Fall nie. Die jungen Frauen machten sich alt, verbargen sich unter dicker, abgerissener Arbeitskleidung und ließen fettige, ungepflegte Haarsträhnen in bleich gemachte Gesichter fallen, die von hässlichen Kopftüchern halb zugedeckt waren (zu dem lange Zeit tabuisierten Thema, vgl.: Grossmann, 1995, 43-63). Erst einige Tage später wird der russische Kommandant verkünden lassen, dass die jungen Frauen nicht mehr wie Großmütter herumzulaufen brauchten. All das weiß ich natürlich nur aus Erzählungen, denn ich war an diesem Tag genau 3 Jahre, 5 Monate und 6 Tage alt. Und vielleicht genau an diesem 3. Mai 1945 hob mich ein russischer Soldat (in meiner späteren Erinnerung musste es unbedingt ein Offizier sein!) auf den Arm, tätschelte und neckte mich scherzhaft und strahlte mich dabei mit großen Augen an. Das ist die allererste Erinnerung meines Lebens. Die allererste, wohlgemerkt! Ich habe mich oft gefragt, warum gerade dieses Bild des mich anlächelnden und in fremden Lauten freundlich auf mich einredenden Rotarmisten so tief in mir haften geblieben ist, als ob es mein ganzes weiteres Leben auf geheimnisvolle Weise beeinflusst hätte. War es die panische Angst vor der Ungewissheit, vor den lauernden, unberechenbaren

\footnotetext{
${ }^{1}$ Es handelte sich um das 8.Mechanische Korps der 49. Armee der 2. Belorussischen Front, das in den letzten Apriltagen von Südosten her in Richtung Ludwigslust vorstieß. 
Gefahren, vor der Rache der Sieger, die sich in den Gesichtern der Erwachsenen eingegraben hatte, die ich instinktiv wahrnahm und die sich nun durch die unerwartete "Menschlichkeit" des vermeintlich „bösen Russen" gleichsam in Luft auflöste? Jedenfalls muss ich eine unendliche Erleichterung verspürt haben, in die Augen eines "Guten" und nicht eines „bösen Wolfs" zu schauen.

Wenn man mich in späteren Jahren, wie es öfter vorkam, danach fragte, warum ich mich mit russischer Geschichte und Kultur befassen würde weswegen man übrigens bis weit über den Kalten Krieg hinaus auch im privaten Verkehr im Westen Deutschlands lange Zeit noch unter einem gewissen Rechtfertigungszwang stand -, so trat mir unweigerlich immer jene meine erste Erinnerung lebendig vor Augen.

Während alles nach Westen strebte, zogen wir ostwärts zu meinen Großeltern mütterlicherseits. Sie gehörten zur kleinen bäuerlichen Oberschicht ihres Dorfes und besaßen außer dem Hof ein Haus, das wegen seiner ungewöhnlichen Architektur von den Dorfbewohnern als „Villa" bezeichnet wurde, in die wir nun einzogen. Mein Großvater war von stattlicher Größe und verströmte in seinem Äußeren die Aura eines "Herrn“ und wohlhabenden Großbauern, der er in jenen Jahren für kurze Zeit noch war. Die Russen hatten ihn, der eine anerkannte Dorfautorität war, vorübergehend zum Bürgermeister ernannt. Als ehemals „Deutschnationaler“, der den Nazis relativ kritisch gegenüber gestanden hatte, erschien er ihnen politisch unverdächtig. Für seine kurzzeitige Verhaftung wegen angeblicher Nichterfüllung des Ablieferungssolls wurden zu Hause vor allem die „deutschen Kommunisten“ und „Spitzel“ verantwortlich gemacht, weniger die Russen, obwohl jene ja nur deren übereifrige Erfüllungsgehilfen waren. Bei meinen Großeltern war zeitweise ein russischer Major einquartiert, der dafür gesorgt haben soll, dass es im Dorf kaum zu willkürlichen Übergriffen gekommen ist. Über den Major sprach man im Hause des Großvaters nur mit Respekt und Hochachtung. Mich faszinierten am meisten seine Uniform und seine blitzblank gewienerten Stiefel.

Es war einer dieser unglaublich heißen Augusttage 1945. Das Dorflag still in der flimmernden Nachmittagshitze. Der Sand unter den Füßen brannte, die Blumen im Garten ließen kraftlos ihre Köpfe hängen, die Hühner, mit offenen Schnäbeln als schnappten sie nach Luft oder schrien um Hilfe, flüchteten unter schattige Büsche, und alle Welt sehnte die Abendkühle herbei. Die beiden unbekannten Männer in Ledermänteln und mit Hut, die dem schwarzen Auto entstiegen waren, das seit geraumer Zeit vor unserem Haus parkte, hatten anderes im Sinn. Sie starrten den Sandweg entlang, der zur Ackerflur meines Großvaters aus dem Dorf heraus führte, und rauchten. Meine Mutter befand sich in hellster Aufregung. Unfähig, einen klaren Gedanken zu fassen, rannte sie kopf- und ziellos von einem Zimmer ins andere, wühlte panisch im Kleiderschrank herum und schaute hinter 
der Gardine ab und an entsetzt auf die beiden Gestalten, die ihr soeben mitgeteilt hatten, dass sie ihren Mann zu einem Verhör in die Kreisstadt nach Parchim bringen müssten.

Vom Ende des Dorfes näherte sich das mit Korngarben hoch beladene Pferdefuhrwerk. Die Männer warfen die Reste ihrer Zigarette weg und blickten angespannt in die Richtung. Als der Leiterwagen die Kreuzung bei unserer „Villa“ erreichte, hielten sie ihn an. Oben auf dem Erntewagen sitzt mein Vater in grauem Knickerbocker mit Hosenträgern und weißem Unterhemd. Ich habe die Szene vor Augen, als sei es gestern gewesen. Mein Vater wird aufgefordert abzusteigen und lässt sich am Strick des Ladebaums herunter. Er wird zum Auto geführt. Eine Jacke darf er mitnehmen, aber ja, selbstverständlich. Handtuch, Seife, Zahnbürste? Ja, natürlich, es ist nur für kurze Zeit, er kommt bald zurück. Es geht lediglich um die „Klärung eines Sachverhalts“. Dieser „Sachverhalt“ stellte sich als „das verbotene Ausgraben einer Leiche" heraus. Die Schwester meiner Mutter war mit ihren drei kleinen Kindern auf dem Weg nach Westen in ein von einem fanatischen SS-Offizier angezetteltes Rückzugsgefecht zwischen die Fronten geraten und von einem Schuss ins Herz tödlich getroffen worden. Mein Vater hatte mit einem Verwandten in einer Nacht- und Nebelaktion die Tote ausgegraben und auf einem Pferdewagen in unser Dorf überführt. Die Männer, Deutsche, beschwichtigen meine Mutter: „Sie brauchen sich keine Sorgen zu machen. Ihr Mann ist bald wieder zu Hause." Ich finde, dass sie nett sind. Einer streicht mir übers Haar. Mein Vater wird in einem schönen Personenwagen gefahren. Im Dorf hat niemand ein Auto und man sieht auch sonst keines. Irgendjemand muss ihn angezeigt haben. Die Vergangenheit holte ihn ein. Unter den Nazis war er vor dem Krieg zeitweise Ortsgruppenleiter gewesen. Das war der eigentliche Grund seiner Verhaftung.

Am nächsten Tag erblickten wir ihn noch einmal hinter dem vergitterten Kellerfenster einer Parchimer Stadtvilla, in der russische Kommandantur und NKWD einquartiert waren. Er wurde in den wenigen Tagen, die er dort war, gut behandelt, weil er den russischen Offizieren auf dem Klavier vorspielte. Dann verschwand er für drei Jahre aus unserem Gesichtskreis und kam in das russische Spezial- und Schweigelager Fünfeichen bei Neubrandenburg [vgl.: Morre 1997; Mironenko, Niethammer, von Plato, 1998]. Das erfuhren wir erst viel später und nur durch Zufall. Für mich änderte sich nicht viel, er war ja auch schon vorher während des Krieges, den er die meiste Zeit als Oberzahlmeister (Obltn) bei der Heeresgruppe Süd in Russland zubrachte, kaum zu Hause gewesen und nur sporadisch für wenige Urlaubstage bei uns aufgetaucht. Fotos zeugen davon. Seine Verhaftung ist meine erste Erinnerung an ihn. Als er nach drei Jahren zurückkehrte, habe ich ihn kaum wiedererkannt. Seine Haare waren schneeweiß. Über seine Leidenszeit im Lager hat er vor uns Kindern bis zu seinem Tod 1968 beharrlich geschwiegen. Auch über seine Soldatenzeit in Russland sprach er nicht. Schmerzhafte, belastende Erlebnisse werden 
verdrängt, man erzählt sie nicht - eine allgemeine Erfahrung. Allerdings haben wir, aus instinktiver Rücksichtnahme vielleicht, auch nie danach gefragt. In vielen Familien gab es damals diese Gesprächsbarriere zwischen den Generationen, wenn die jüngste deutsche Vergangenheit und der Krieg im Osten zur Sprache kamen [vgl.: Heer, Naumann].

Szenenwechsel. Es wird im Spätherbst 1945 gewesen sein, als meine Mutter und ich in der Abenddämmerung hinter den Fenstergardinen des Wohnzimmers verstohlen die nicht enden wollenden Kolonnen von Russen beobachteten, die mit ihren Panje-Wagen durch unser Dorf in die umliegenden Wälder zogen. Unheimlich war das Schweigen, man hörte fast keinen Laut, keine Rufe, keine Befehle, nur das Schnaufen der Pferde. Als wenn die Soldaten, auf plötzliche Gefahr gefasst, die dörfliche Szenerie angespannt im Auge hatten, wie wir $\mathrm{s}$ i e hinter unserer Gardine. Es konnte aber auch der Eindruck ihrer großen Erschöpfung und Müdigkeit entstehen und dass sie nichts weiter im Sinn hatten, als endlich das nächtliche Biwak zu erreichen. Wer die Russen waren, woher sie kamen und warum sie hier waren, wusste ich nicht. Später entnahm ich den Gesprächen der Erwachsenen, dass die Deutschen den Krieg verloren hatten und die Russen die Sieger waren, was ihre Anwesenheit bei uns erklärte. Darüber, was vor dem Krieg war und warum es Krieg gegeben hatte, hat keiner mit mir gesprochen, ich hätte es wohl ohnehin nicht verstanden.

Fasziniert sahen wir Dorfkinder zu, wenn die russischen T34Panzer die breiteste und tiefste Stelle unseres Baches neben einer alten Steinbrücke durchquerten und nur noch der Geschützturm aus dem Wasser ragte oder fast gänzlich verschwand und sie dann, triefend vor Wasser, als wäre ihr Bauch randvoll damit, ans andere Ufer gelangten. Es irritierte mich, dass für die einen die Russen die "Guten" waren, für andere die „Bösen“. In der Schule, in die ich 1948 als Sechsjähriger kam, hörten wir nichts Schlechtes über sie. Dennoch war es mir schleierhaft, warum wir in Häusern lebten und sie in Wäldern, wo sie uns doch besiegt hatten [Naimark].

Im Repertoire des gemischten Dorfchores, den mein Vater nach seiner Rückkehr aus Neubrandenburg leitete, spielte russisches Gesangsgut eine gewisse Rolle. Besonders die „Abendglocken“ wurde mit Inbrunst gesungen und man versäumte nicht, mit bedeutungsvollem Blick und gesenkter Stimme zu erwähnen, dass dies Stalins Lieblingslied sei, was ihn mir sympathisch machte, da ich nichts anderes über ihn wusste. Das Lied war traurig, also war auch Stalin traurig.

Ein anderes russisches Kulturgut aus damaliger Zeit ist mir ebenfalls in unauslöschlicher Erinnerung geblieben: Alexander Fadeevs verfilmter Sowjetklassiker "Die Neunzehn", in dem eine rote Partisanenabteilung im Fernen Osten gegen Japaner und „weiße“ Truppen des Admirals Koltschak kämpft. Dieser im Saal des Dorfkrugs gezeigte Film barg 
für uns mit Flitzbogen und Katapulten "Indianer“ spielende Knaben ein hohes Identifikationspotential, wobei die roten Helden mit den dann später in Hamburg von mir bewunderten „Western“-Größen wie Jesse James, Wyatt Earp oder Zorro durchaus mithalten konnten. Die politisch-ideologischen Hintergründe des Films blieben uns natürlich verschlossen.

In der 5. Klasse, kurz vor der Flucht meiner Eltern aus der DDR nach Westberlin im Frühjahr 1953, lernte ich noch das russische Alphabet und erinnere mich an ein Schaubild im Russischunterricht, auf dem zu lesen stand: „Nina, Nina, tam kartina, eto traktor i motor. ${ }^{\text {“2 }}$

Die Übersiedlung nach Westdeutschland war mit einem spürbaren Identitätsverlust verbunden, bei dem sich auch die $\mathrm{r}$ u s s i s c h e $\mathrm{n}$ Erlebnisanteile meiner ostdeutschen Knabenexistenz in die tieferen Schichten meines Bewusstseins absenkten, verdrängt wurden und gleichsam in den toten Zustand der Vergessenheit gerieten. „Russisches“ war mir nur noch als hauptsächlich durch Medien vermittelte ferne Großereignisse aufständische Steinewerfer auf sowjetische Panzer in Ostberlin am 17. Juni 1953, Niederwerfung des ungarischen Volksaufstands durch die Sowjets im November 1956, Berliner Mauerbau im August 1961 - und dann im Gewand des als bedrohlich empfundenen Sowjetkommunismus mehr oder weniger gegenwärtig, aber natürlich ohne den hohen Grad emotionaler Betroffenheit, wie sie sich üblicherweise durch das unmittelbare persönliche Erleben einstellt.

Das änderte sich schlagartig, als ich, Gymnasiast noch und einige Monate vor dem Abitur, 1961 auf einer Party meine spätere Frau kennen lernte. Das „Russische" kehrte durch ihre Familiengeschichte nach und nach massiv in mein Leben zurück. Schon bei der ersten Begegnung erfuhr ich, dass sie eine russische Großmutter hatte, die sich beharrlich einer korrekten deutschen Sprechweise und Grammatik verweigerte und zur Freude der Enkelkinder auf Russisch zu fluchen pflegte, was diese in den Besitz eines zwar nur sehr begrenzten Sprachschatzes, aber eines dafür umso charakteristischeren russischen Kulturguts brachte. Diese „Babuschka“ Olga war mit ihrem deutschbaltischen Mann, einem Psychiater, und zwei kleinen Töchtern 1918 vor den Bolschewiken aus Charkow nach Riga geflohen und dann später als Folge des Hitler-Stalin-Paktes nach Posen umgesiedelt worden. Ihre jüngere Tochter, die mit mir als Zweiundneunzigjährige 2010 nach Moskau reiste, um dort zum ersten Mal ihre russische Verwandtschaft zu besuchen, war 1940 in Leipzig, wo sie am dortigen Konservatorium Musik studierte, vom evangelischen zum russisch-orthodoxen Glauben konvertiert, was damals auf dem Höhepunkt der allgemeinen „Führer"-Hysterie und Siegeseuphorie durchaus als ein Zeichen innerer Widerständigkeit gegen das Nazi-Regime aufgefasst werden konnte.

${ }^{2}$ Zum Einfluss sowjetrussischer Kultur in der unmittelbaren Nachkriegszeit vgl.: [Hartmann, Eggeling]. 
Die Großeltern väterlicherseits stammten ebenfalls aus Russland bzw. waren russische Untertanen deutschbaltischer Herkunft. Der zarentreue Großvater Wladimir A., dessen Vorfahren im 18. Jahrhundert in das zum Russischen Reich gehörende Baltikum eingewandert waren und die sich als Unternehmer und im Dienst der Zaren erfolgreich in die russische Gesellschaft integriert hatten, ${ }^{3}$ besaß ein Gut bei Saratov und wurde während der Revolution 1917 umgebracht. Der Familienüberlieferung zufolge sollen sich die leibeigenen Bauern bei der Witwe feierlich entschuldigt haben, „sie hätten es nicht gewollt“. Diese Großmutter „Oma Tasche“, wie sie später von ihren Enkeln scherzhaft genannt wurde, floh mit ihren beiden minderjährigen Söhnen nach Riga, das ihre Heimatstadt war, und gelangte durch die Umsiedlung 1939 mit ihnen und einer Schwiegertochter ebenfalls in den nationalsozialistischen "Mustergau“ Posen. Hier hat meine Frau Freya das Licht der Welt erblickt.

In beiden großelterlichen Familien bestand also eine starke lebensgeschichtliche und mithin auch mentale Affinität zu Russland und eine ebenso stark ausgeprägte antibolschewistische Einstellung, wie sie bekanntlich in deutschbaltischen Kreisen und bei russischen Emigranten ganz überwiegend anzutreffen war.

Bereits gegen Ende meiner Schulzeit und während meines Wehrdienstes habe ich mich, jetzt inspiriert durch die Beziehung zu meiner Frau, erstmals intensiver auch mit russischer Literatur befasst. Die russischen Klassiker standen auf dem Bücherregal von „Babuschka“ Olga, welche den Gogol'schen Schalk im Nacken hatte und ihre Sehnsucht nach Russland und dem ukrainischen Sternenhimmel mit Puschkins Versen beschwichtigte. Meine Entscheidung, von der Germanistik zur Slawistik zu wechseln, war somit eine zuvorderst emotionale, das heisst durch die Familiengeschichte angestoßene, für die es allerdings auch gewichtige rationale Argumente gab. Dass ich Geschichte studieren würde, stand für mich von vornherein fest. Mein Interesse für dieses Fach war nicht zuletzt das Resultat eines für damalige Verhältnisse sehr progressiven Geschichtsunterrichts durch einen hervorragenden Lehrer auf der Oberstufe des Gymnasiums. Dieser Lehrer Rudolf Lüdemann schärfte nicht nur unseren kritischen Blick für die jüngste deutsche Vergangenheit, sondern versuchte uns Schülern als Konsequenz aus diesem dunkelsten Kapitel der deutschen Geschichte den Geist der Versöhnung auch mit den ehemaligen östlichen Kriegsgegnern zu vermitteln, was in der politisch und medial aufgeheizten Stimmung des Kalten Krieges durchaus nicht selbstverständlich war.

Als ich im ersten Semester das Vergnügen hatte, bei Paul Johansen in Hamburg eine Vorlesung über „Russische Geschichte“ zu hören, stand für mich fest, dass ohne Kenntnis der russischen Sprache eine

\footnotetext{
${ }^{3}$ Vgl. dazu demnächst meinen Aufsatz „Porträt eines Weitläufigen“ (erscheint 2014 in den „Forschungen zur baltischen Geschichte“); [Wette, Überschär].
} 
Spezialisierung auf die osteuropäische Geschichte, zu der ich mich auch unter dem Eindruck dieser Vorlesung entschlossen hatte, schlechterdings unmöglich sei. Der Wechsel von der Germanistik zur Slawistik war deshalb nur folgerichtig.

Auf den verschlungenen Pfaden von Kindheit und Jugend zum frühen Erwachsenenalter war mir somit am Wegesrand immer wieder „Russisches“ in verschiedener Gestalt und Intensität begegnet, so dass letztlich, wie es mir in der Rückschau erscheint, gleichsam zwangsläufig alles für mich auf Russland, auf seine Geschichte, Kultur und Sprache hinausgelaufen ist. Die Bekanntschaft mit der Familie und den Vorfahren meiner Frau sowie die nun wieder stärker in mein Bewusstsein rückende Erinnerung an meine eigene Kindheit in der Sowjetzone und der DDR hatten zweifellos einen kaum zu überschätzenden Anteil daran. Mit Paul Johansen (1901-1965) in Hamburg und Manfred Hellmann (1912-1992) in Münster bekam ich es mit Universitätslehrern zu tun, die lebensgeschichtlich mit Russland, der Sowjetunion und den baltischen Staaten Lettland und Estland aufs engste verbunden waren. Mein Doktorvater Manfred Hellmann gehörte zu jenem heute selten gewordenen Typus des Gelehrten, der mit hoher wissenschaftlicher Kompetenz ein überaus breites historisches Forschungsspektrum abzudecken imstande war und in der mittelalterlichen deutschen Geschichte ebenso zu Hause war, wie in der russischen, baltischen oder venezianischen [siehe den Nekrolog von Carsten Goehrke: Jahrbücher für Geschichte Osteuropas]. Als er mir die Abfassung des Abschnitts über das "Kiever Reich“ im renommierten „Handbuch der Geschichte Russlands" übertrug, war das ein großer Vertrauensvorschuss für einen jungen Historiker, zumal die wissenschaftliche Laufbahn, die er mir nahe gelegt hatte, damals nicht unbedingt ein prioritäres Berufsziel für mich war [Maier]. Aber das ist eine andere Geschichte.

Als ich meine Frau kennen lernte, wusste sie noch nicht, dass ihr Vater, der fließend Russisch sprach und 1954 bei einem Verkehrsunfall ums Leben kam, mit Kriegsbeginn gegen die Sowjetunion den berüchtigten SSEinsatzgruppen [Krausnick, Einsatzgruppen] angehört hatte und zwischen 1941-1943 SD-Chef in einem weißrussischen Bezirk gewesen war. In der Endphase des Krieges gehörte er zum SS-Verbindungsstab im Umfeld des ehemaligen Sowjetgenerals Andrej Wlassow. Das alles haben wir erst viel später erfahren. Hätten wir es gewusst, hätte mich das in meinem Entschluss, mich mit Russland und seiner Geschichte zu beschäftigen, nur noch zusätzlich bestärkt. 
$* * *$

\section{СЕМЕЙНАЯ ИСТОРИЯ И ИНТЕРЕС К РОССИИ}

Третьего мая в нашу деревню пришли русские ${ }^{1}$. О подразделениях 2 -го Белорусского фронта как об особенно индоктринированных среди гражданского населения шла дурная слава. Большинство личного состава из 53 тыс. военнослужащих, около половины которых были комсомольцами и коммунистами, было предположительно родом из Белоруссии [cp.: Schulz-Naumann, S. 156], особенно пострадавшей от террора и преступлений немецких оккупантов. В школьном здании, где мы как учительская семья проживали, всех сковал шок от страха ожидания. Большинство помещений школы было до отказа заполнено людьми. Война на востоке гнала массу беженцев на запад. Каждый вечер в здание школы приходили жители нашей деревни, чтобы переночевать здесь, боясь оставаться в своем доме и чувствуя себя в безопасности среди множества людей.

В саду крестьянской усадьбы напротив были найдены трупы членов семьи, проживавшей там, - супругов и их двух сыновей. Некоторые жители деревни говорили, что они слышали крики. Крестьянина ненавидели военнопленные, работавшие в его хозяйстве. Возможно, это было самоубийство, но обстоятельства смерти остались невыясненными.

Молодые женщины старались выглядеть старухами, одеваясь в старые разодранные рабочие лохмотья. Жирные пряди волос спадали на их неестественно бледные лица, наполовину прикрытые безобразными платками [см. об этом: Grossmann, S. 43-63]. Только через несколько дней русский комендант объявил, что молодым женщинам нет более нужды одеваться подобно старухам. Все это мне известно, конечно, только из рассказов взрослых, потому что мне было тогда всего лишь три года пять месяцев и шесть дней. И, возможно, именно в тот день, 3 мая 1945 г., меня взял на руки один русский солдат (в моей памяти отложилось, что это обязательно должен был быть офицер!). Он трепал меня по щеке и шутил, смотря на меня сияющими глазами. Это первое воспоминание в моей жизни. Самое первое! Я часто спрашивал себя, почему в мою память так глубоко запал именно этот образ улыбающегося и шутящего со мной на непонятном мне языке красноармейца, таинственным образом повлиявшего, возможно, на всю мою жизнь. Был ли это панический страх перед неизвестным, перед непредсказуемыми опасностями и местью победителей, застывший на лицах взрослых и отразившийся в моем подсознании, который превратился теперь в ничто благодаря неожиданной «человечности» якобы «злого

\footnotetext{
${ }^{1}$ Речь идет о 8-м моторизованном корпусе 49-й армии 2-го Белорусского фронта, продвигавшемся в первые апрельские дни в сторону Людвигслюста.
} 
русского»? Во всяком случае, я, кажется, почувствовал беспредельное облегчение, когда заглянул в глаза «доброго», а не «злого волка».

И когда меня впоследствии спрашивали, что случалось нередко, почему я занимаюсь русской историей и культурой, в эти моменты у меня пред глазами всегда возникал образ того самого солдата.

В то время как все стремились на Запад, мы переехали к моим бабушке и дедушке по материнской линии на восток. Они принадлежали к узкой прослойке деревенской элиты. Кроме деревенской усадьбы, в их собственности находился дом необычной архитектуры, получивший среди односельчан название «виллы», в котором мы и обосновались. У моего деда была статная фигура, он обладал обаянием «барина» и крупного зажиточного крестьянина, которым он мог оставаться тогда уже недолго. Русские назначили его, пользовавшегося большим авторитетом среди односельчан, временным бургомистром. У них, хотя он был немцем по национальности, он не вызывал подозрений в политической неблагонадежности, так как относился довольно критично к нацистам, симпатизируя консервативной Немецкой национальной народной партии (Deutschnationale Volkspartei, DNVP). Когда впоследствии его арестовали на непродолжительное время из-за якобы невыполненной нормы поставки, у нас в семье в этом обвиняли прежде всего «немецких коммунистов» и «шпиков» и менее всего русских, хотя их немецкие помощники и были всего лишь чересчур старательными исполнителями воли последних. Какое-то время в доме моего дедушки был расквартирован один русский офицер, позаботившийся о том, чтобы в деревне практически не было произвола и насилия. Об этом майоре в нашей семье всегда говорили с большим уважением. Мне больше всего запомнились его форма и до блеска начищенные сапоги.

Это был один из тех невероятно жарких августовских дней 1945 г. Деревня тихо лежит в струящемся полуденном зное. Песчаная почва горит под ногами, цветы в саду в изнеможении опустили свои головы, обессиленные куры хватают приоткрытыми клювами воздух, тревожно кудахтая, словно зовя на помощь, и скрываясь в тенистых кустах. Весь мир застыл в ожидании вечерней прохлады. Два незнакомца в черных кожаных плащах и шляпах вышли из «воронка», стоящего уже долгое время припаркованным у нашего дома. Очевидно, их мысли заняты другим. Они курят не спеша. Взгляд их прикован к дороге, ведущей из деревни прямо к полевым угодьям деда. Моя мать крайне взволнована. Неспособная сосредоточиться на одной мысли, она в ужасе снует бесцельно по комнатам, роется в панике в платяном шкафу, что-то ища, и выглядывает время от времени из-за гардин, чтобы бросить взгляд на пришельцев. Те только что сообщили ей, что приехали забрать ее мужа на допрос в районный центр Пархим.

В конце деревни показалась наконец-то повозка, нагруженная высоко возвышающимися снопами. Незнакомцы бросили недокуренные сигареты и пристально посмотрели в ее сторону. Когда телега по- 
равнялась с ними, выехав на перекресток напротив нашей «виллы», они сделали знак остановиться. На самом верху сидел мой отец в брюках гольф и белой нижней сорочке. Эта сцена у меня до сих пор перед глазами, как будто это было вчера. По требованию незнакомцев отец слезает с повозки, спускаясь по веревке грузовой стрелы. Его ведут к машине. Разрешают взять с собой куртку: «Да, само собой разумеется...» - «Полотенце, мыло, зубная щетка?» - «Да, конечно...» Речь идет якобы всего лишь о «выяснении некоторых обстоятельств». Эти «некоторые обстоятельства» означали не что иное, как «запрещенное извлечение тела покойника из земли». Сестра моей матери, по пути на Запад с тремя маленькими детьми, попала под перекрестный огонь, когда некий фанатично настроенный офицер СС устроил «арьергардный бой» при отступлении. Она погибла на месте: пуля прострелила ей сердце. Мой отец с одним из своих родственников поехал на место гибели, чтобы забрать погибшую. Под покровом ночи они выкопали тело несчастной и привезли на телеге в нашу деревню. Мужчины в кожаных плащах, немцы, успокаивают мою мать: «Не беспокойтесь. Ваш муж вернется». Я нахожу их симпатичными. Один из них гладит меня по голове. Моего отца увозят на красивом легковом автомобиле. В деревне ни у кого нет машины, да никто таких и не видел здесь. Кто-то донес на моего отца, и прошлое настигло его. При нацистах до войны он некоторое время был руководителем местной группы НСДАП (Ortsgruppenleiter). Это и было истинной причиной его ареста.

На следующий день мы увидели его еще раз - за решеткой подвального окна одной из городских вилл Пархима, где находилась комендатура и отделение НКВД. В те несколько дней, пока он находился там, с ним хорошо обращались, так как он играл русским офицерам на пианино. Потом он пропал на три года из нашего поля зрения. Его интернировали в специальный лагерь НКВД в Фюнфайхен под Нойбранденбургом [см.: Morre; Mironenko, Niethammer, Plato]. Мы узнали это значительно позднее и по чистой случайности. Лично для меня мало что изменилось. Во время войны он тоже почти не бывал дома и только иногда приезжал в отпуск на несколько дней, подтверждением этому служат фотографии. Он служил на восточном фронте в группе армий «Юг» в звании оберцальмейстера (Oberzahlmeister, Oblt.). Его арест - это мое первое воспоминание о нем. Когда он вернулся после трех лет лагеря, я его узнал с трудом. Он был седой как лунь. О своих страданиях в лагере он упорно молчал вплоть до своей смерти в 1968 г. Также ничего не рассказывал о своей военной службе в России. Болезненные, тяжелые события люди пытаются забыть, о них, как известно, не говорят. К тому же, возможно, повинуясь внутреннему такту, мы никогда не спрашивали его об этом. Во многих семьях существовал непреодолимый барьер между поколениями, когда речь заходила о недавней немецкой истории и войне на востоке Европы [см.: Heer, Naumann]. 
Смена декораций. Это было, вероятно, поздней осенью 1945 г. Смеркалось, прячась с матерью за гардинами, мы наблюдаем бесконечную колонну фургонов с красноармейцами, медленно двигающуюся по деревне в сторону окрестных лесов. Совершенное безмолвие. Не слышно ни команды, ни звука,- только фырчанье лошадей. Как будто солдаты, ожидая внезапной опасности с любой стороны, зорко всматриваются в проплывающие мимо них деревенские дома. Хотя и могло показаться, что они от усталости и изнеможения не могли думать ни о чем другом, как только о ночном привале и сне. Кто были эти русские, откуда они пришли и почему они были здесь, я не знал. Из разговоров взрослых я узнал, что немцы проиграли войну и русские победили. Это и объясняло их пребывание здесь. О том, что было до войны и почему была война, мне никто не говорил. Я, вероятно, и не понял бы ничего.

Как зачарованные деревенские ребята смотрели на русские танки Т-34 при форсировании нашего ручья в самом широком и глубоком месте, рядом со старым каменным мостом. Они заходят в воду, и видна только их башня, которая на какой-то момент пропадает под водой. И вот они выползают на противоположный берег, со стекающей с них водой, как будто они полны ею до краев. Меня приводило в недоумение, что для одних русские были «хорошими», а для других «плохими». В школе, в которую я пошел в шесть лет в 1948 г., я ничего о них не слышал плохого. И все же, мне было непонятно, почему мы жили в домах, а они - в лесу [см. об этом: Naimark].

В репертуаре нашего смешанного деревенского хора, которым руководил мой отец после своего возвращения из Нойбранденбурга, были и русские песни. Особой любовью пользовалась «Вечерний звон», и между делом не упускалась возможность упомянуть со значением во взгляде и низким голосом, что это любимая песня Сталина. Это делало его симпатичным в моих глазах, тем более что больше ничего о нем я не знал. Песня была грустной, а значит, и Сталин был грустным.

Неизгладимое впечатление произвел на меня также экранизированный роман Александра Фадеева «Девятнадцать». Красный партизанский отряд на Дальнем Востоке воюет против японцев и белой армии адмирала Колчака. Этот фильм, показанный в трактире нам, деревенским мальчишкам, игравшим с арбалетами и катапультами в «индейцев», содержал в себе большой идентификационный потенциал. Причем красные герои ни в чем не уступали знаменитым героям вестернов Джесси Джеймсу, Уайетту Эрпу или Зорро, которыми я восхищался позднее в Гамбурге. Политический и идеологический контекст фильма, конечно, оставался нам недоступен.

В пятом классе, незадолго до бегства моих родителей из ГДР в Западный Берлин (начало 1953 г.), я еще успел выучить русский алфавит. Вспоминаю наглядный плакат с занятий по русскому языку: «Нина, Нина, там картина. Это трактор и мотор»².

\footnotetext{
${ }^{2}$ О влиянии советской культуры в послевоенное время см.: [Hartmann, Eggeling].
} 
Переезд в Западную Германию был связан с ощутимой потерей идентичности, обусловленной моим детским и отроческим опытом в ГДР. Воспоминания о русской составляющей моего восточногерманского бытия отодвинулись на второй план, погрузились в пассивные слои сознания и были в конечном итоге преданы забвению. С тех пор «русское» было связано для меня в основном со значительными, но далекими событиями, отражавшимися средствами массовой информации: люди, бросающиеся с булыжниками на советские танки в восточном Берлине 17 июня 1953 г., подавление народного восстания в Венгрии в ноябре 1956 г., строительство Берлинской стены в августе 1961 г. «Русское» встречалось под маской угрожающего советского коммунизма и воспринималось тогда, конечно, без того сильного эмоционального участия, возможного, как правило, при непосредственной личной вовлеченности в события.

Это положение вещей изменилось решительным образом за несколько месяцев до окончания гимназии на одной из вечеринок в 1961 г., когда я познакомился со своей будущей женой. «Русское» снова постепенно, но основательно вернулось в мою жизнь через историю ее семьи. Уже при первом знакомстве я узнал, что у нее была русская бабушка, упрямо игнорировавшая корректный немецкий акцент и правила грамматики. К радости своих внучат, она имела обыкновение ругаться по-русски, отчего последние приобрели, правда лишь незначительный, словарный запас, но зато весьма характерное достояние русской культуры. «Babushka» Ольга бежала в свое время в 1918 г. от большевиков со своим мужем-психиатром из прибалтийских немцев и двумя маленькими дочерьми из Харькова в Ригу. Оттуда они были переселены вследствие пакта Молотова - Риббентропа (Hitler-Stalin-Pakt) в Познань. Ее младшая дочь, будучи уже 92-летней, ездила со мной в Москву в 2010 г., чтобы в первый раз в жизни навестить свою русскую родню. Учась в 1940 г. в Лейпцигской консерватории, она перешла из лютеранства в православие в то время, когда в Германии был пик всеобщей истерии в отношении «вождя» и упоения победой, что, несомненно, можно было оценить и как знак внутреннего сопротивления нацистскому режиму.

Дедушка и бабушка моей жены со стороны отца также были родом из России и российскими подданными из прибалтийских немцев. Оставшийся верным царю ее дед Владимир А., чьи предки приехали на русскую службу в Остзейские провинции в XVIII в. и интегрировались в российское общество ${ }^{3}$, владел имением в Саратове и погиб во время Революции 1917 г. Согласно семейной легенде, крестьяне попросили у вдовы торжественно прощения: «они этого не хотели». Эта «бабушка-сума», как ее в шутку прозвали внучата, бежала со своими маленькими сыновьями в Ригу, где она родилась, а оттуда также

${ }^{3}$ Подробнее см. мою статью „Porträt eines Weitläufigen“ (планируется к публикации в 2014 г. в сборнике «Forschungen zur baltischen Geschichte»). 
была переселена в 1939 г. с ними и со своей невесткой, матерью моей жены, в Познань (Posen), в так называемое национал-социалистическое «образцовое рейхсгау» Вартеланд. Там же появилась на свет моя жена Фрейя.

Следовательно, история семей моей жены по дедушкиной и бабушкиной линиям тесно связана с Россией как личной судьбой, так и душевной привязанностью. В то же время у них существовали сильно выраженные антибольшевистские настроения, характерные для большинства прибалтийских немцев и белой эмиграции.

Уже незадолго до окончания гимназии и во время службы в Бундесвере я, воодушевленный знакомством со своей будущей женой, впервые интенсивно занялся русской литературой. Произведения классиков стояли у «babushki» Ольги, обладавшей гоголевским юмором, на книжной полке. Свою тоску по России и украинскому звездному небу она утоляла пушкинскими стихами и гоголевскими повестями. Принятое мною решение в первом семестре перейти от германистики к славистике было мотивировано прежде всего эмоциями, связанными с семейной историей. Но существовали и чисто рациональные аргументы. Мне с самого начала было ясно, что я буду изучать историю. Интерес к ней пробудил выдающийся учитель истории старших классов гимназии Рудольф Людеманн. Его образцовое преподавание не только поощряло наш критический взгляд на новейшую немецкую историю - время Третьего рейха 1933-1945 гг., более того, Людеманн пытался показать нам, что единственным следствием этой самой темной главы нашей истории должно стать примирение с нашими бывшими врагами на востоке Европы. Данная позиция вовсе не была сама собой разумеющейся в условиях политики холодной войны и подогреваемых средствами массовой информации настроений.

Когда я в первом семестре в Гамбургском университете прослушал лекцию по русской истории Пауля Иогансена, я должен был, конечно, осознать, что без знания русского языка специализация по истории Восточной Европы решительно невозможна.

Со времени моего детства и юношества, вплоть до взрослого возраста, судьба вновь и вновь сводила меня с «русским» в самых разных ситуациях и контекстах. Так что, как это мне видится сейчас, все как будто неизбежно сводилось к России, к ее истории, культуре и языку. Знакомство с семьей моей жены и с историей ее предков, а также все чаще появляющиеся воспоминания о моем детстве в советской зоне и в ГДР, несомненно, повлияли на это. Благодаря своим учителям Паулю Иогансену (1901-1965) в Гамбурге и Манфреду Хельманну (1912-1992) в Мюнстере я получил возможность соприкоснуться с учеными, жизнь которых теснейшим образом была связана с Россией, Советским Союзом и странами Балтии, особенно Эстонией и Латвией. Мой научный руководитель Манфред Хельманн принадлежал к тому типу ученых, редко встречающихся сегодня, ко- 
торый соединял в себе высокую научную компетенцию с широким диапазоном научных исследований. Он был прекрасным знатоком времени немецкого Средневековья, русской, прибалтийской и даже венецианской истории [см. некролог Карстена Гёрке: Jahrbücher für Geschichte Osteuropas, S. 40]. Знаком большого доверия ко мне, молодому историку, было поручение написать главу по истории Киевской Руси („Das Reich von Kiev“) в престижном научном издании «Пособие по истории России» („Handbuch der Geschichte Russlands“). Тем более что научная карьера не стояла для меня в то время на первом месте [см.: Maier]. Но это уже другая история.

Когда я познакомился со своей женой, она не знала на тот момент ничего о том, что ее отец, прекрасно говоривший по-русски и погибший в 1954 г. в автокатастрофе, в начале войны с Советским Союзом состоял в пресловутых оперативных группах CC (SS-Einsatzgruppen) [cм.: Krausnick], а в 1941-1943 гг. начальником службы безопасности (Sicherheitsdienst $=\mathrm{SD}$ ) в одном белорусском районе. После этого и до окончания войны он служил в оперативном штабе СС в окружении бывшего советского генерала Андрея Власова. Обо всем этом мы узнали много лет спустя. Если бы мы и знали об этом, я наверняка был бы еще более укреплен в своем решении заниматься Россией и ее историей.

Grossmann A. The Rape of German Women by Occupation Soldiers // Quaestion of Silence. 1995. October 2. P. 43-63.

Hartmann A., Eggeling W. Sowjetische Präsenz im kulturellen Leben der SBZ und frühen DDR 1945-1953. Berlin, 1998.

Heer H., Naumann K. Vernichtungskrieg. Verbrechen der Wehrmacht 1941 bis 1944. Hamburg. 2. Aufl. 1995.

Jahrbücher für Geschichte Osteuropas. 1992. 40. S. 477-479.

Krausnick H., Einsatzgruppen H. Die Truppen des Weltanschauungskrieges 1938-1942.

Frankfurt/M., 1985.

Maier L. Hartmut Rüß - 70 Jahre // Jahrbücher für Geschichte Osteuropas. 2012. 60. S. 319-320.

Mironenko S., Niethammer L., Plato A. von. Sowjetische Speziallager in Deutschland 1945-1950. 2 Bd. Berlin, 1998.

Morre J. Speziallager des NKWD. Sowjetische Internierungslager in Brandenburg, 1945-1950. Potsdam, 1997.

Naimark N. Die Russen in Deutschland. Die sowjetische Besatzungszone 1945 bis 1949. Berlin, 1997.

Schulz-Naumann J. Mecklenburg 1945. München, 1989.

Wette S. W., Überschär G. Kriegsverbrechen im 20. Jahrhundert. Darmstadt, 2001. S. $406-418$.

Hartmut Rüß (Хартмут Рюсс), prof.

Germany. Münster

Westfälische Wilhelms-Universität (WWU)

ruessbockhorst@t-online.de 